\title{
Miranda
}

Revue pluridisciplinaire du monde anglophone /

Multidisciplinary peer-reviewed journal on the English-

speaking world

23 | 2021

Modernist Exceptions

\section{Claire Gheeraert-Graffeuille, and Vaughan, Geraldine (eds). Anti-Catholicism in Britain and Ireland}

\section{Rachel Rogers}

\section{OpenEdition}

\section{Journals}

Electronic version

URL: https://journals.openedition.org/miranda/41973

DOI: $10.4000 /$ miranda.41973

ISSN: 2108-6559

\section{Publisher}

Université Toulouse - Jean Jaurès

\section{Electronic reference}

Rachel Rogers, "Claire Gheeraert-Graffeuille, and Vaughan, Geraldine (eds). Anti-Catholicism in Britain and Ireland", Miranda [Online], 23 | 2021, Online since 11 October 2021, connection on 29 November 2021. URL: http://journals.openedition.org/miranda/41973; DOI: https://doi.org/10.4000/miranda. 41973

This text was automatically generated on 29 November 2021.

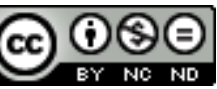

Miranda is licensed under a Creative Commons Attribution-NonCommercial-NoDerivatives 4.0

International License. 


\title{
Claire Gheeraert-Graffeuille, and Vaughan, Geraldine (eds). Anti- Catholicism in Britain and Ireland
}

\author{
Rachel Rogers
}

\section{REFERENCES}

Claire Gheeraert-Graffeuille, and Vaughan, Geraldine (eds). Anti-Catholicism in Britain and Ireland, 1600-2000: Practices, Representations and Ideas. Basingstoke: Palgrave Macmillan, 2020, ISBN 978-3-030-42881-5 


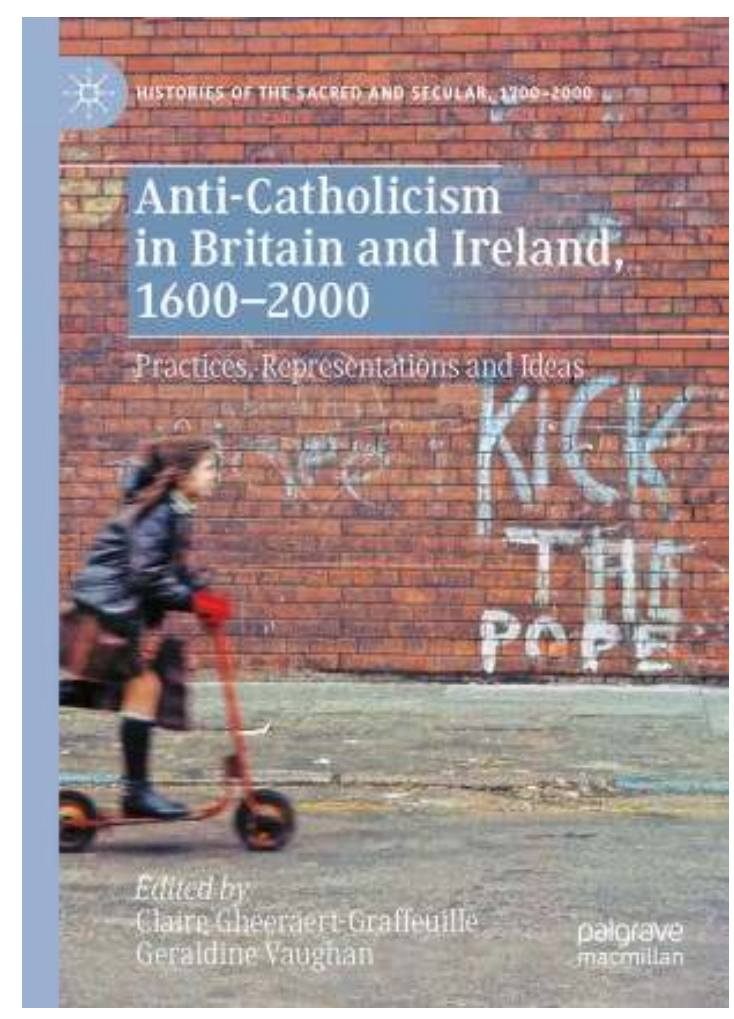

1 This collection of essays delves into the way in which expressions of anti-Catholicism have manifested themselves and been negotiated and countered in both discourse and the lived experience of British and Irish people from the early $17^{\text {th }}$ century through to the contemporary period. As the editors explain in the introduction, although broadly influenced by the 'cultural turn' in scholarly enquiry, no attempt is made in the volume to square the conclusions reached by the authors with a particular historiographical trend since, in their view, instances of anti-Catholic sentiment escape "teleological narration". The aim rather is to emphasise how such instances have been "episodic, more or less rooted in common world views" across these four centuries (4). This absence of a clear and comprehensive historical framework to the study necessitates a certain degree of familiarity with the subject matter for readers to fully grasp the intricacies of the cultural processes at work. This collection therefore appears to be aimed at scholars and students already acquainted with the historical developments across the period.

2 The book starts from the convincing premise that case studies which investigate the inner workings of anti-Catholicism and the paradigmatic shifts at work in past society can help to overcome neatly polarized views of confessional tension and can highlight instance of 'cross-pollination' between religious affiliations and tendencies. The individual essays are therefore organized thematically, though within each part, a chronological coherence is adhered to. Some sections (part two for instance, which is primarily devoted to $17^{\text {th }}$-century case studies) appear more focused on a particular time frame than others. It is an ambitious and searching collection of high-calibre studies, bringing together a host of eminent scholars working in Britain, Ireland and France. From the outset, the different contributions engage with dilemmas and debates -"culture wars" and "identity panics" (Borot, 34), moral disquiet and incendiary propaganda-which remain highly relevant in our contemporary societies. 
3 This present-day resonance is felt from the beginning in Part 1 which focuses on the everyday experience of oppression experienced by Catholics in Britain and the obstacles to 'living together' in the $17^{\text {th }}$ and $18^{\text {th }}$ centuries. Luc Borot's magisterial article, which opens the collection, investigates the resistance which English Catholics put up to state-sponsored religious persecution in the 1600s. The author shows how resistance to anti-Catholicism could be firmly grounded in the view that the Protestant Reformation of the $16^{\text {th }}$ century had abruptly and unfairly deprived Catholics of their long cultural lineage, rendering their faith-inseparable in the national imagination from treachery and foreign invasion-incompatible with patriotism. Nevertheless, the author suggests that Catholics could "broker compromises" (31) in $17^{\text {th }}$-century England (and further afield) to secure relief and spiritual sustenance, particularly after the accession of Charles II to the throne.

4 Such scope for Catholics to negotiate space and security within a Protestant regime is also highlighted in Clotilde Prunier's article on $18^{\text {th }}$-century Scotland. The author's contention is that while the British government failed to abrogate penal laws instituted in the late 1770s, Scottish Catholics had nevertheless secured sufficient "social recognition" (39) by this stage to protect their interests. Scottish Catholics pointed to the inquisitorial strategies of a persecuting British state which, in adopting practices reminiscent of the worst abuses of foreign Catholic powers, tainted its own reputation for tolerance in matters of conscience. In doing so, Catholics reclaimed a place for themselves within the discourse of British patriotism and distanced themselves from accusations of collusion with hostile foreign enemies. The campaign against Catholic relief in the 1770s was however particularly virulent in Scotland, sustained by Evangelical Protestants and at a time when the work of major thinkers of the Scottish Enlightenment was being showcased internationally. The claim however that "the penal laws were repealed without any commotion" in England (51) needs to be tempered given the week of violent protests which occurred in June 1780 in London against the decision to open access to the British armed forces to Catholics as the loss of the American colonies was imminent.

The theme of 'everyday anti-Catholicism' in England is taken up by Carys Brown in her valuable contribution to the collection which concludes the first part of the book. While not specifically countering the widely-held claim that different confessional communities lived relatively peaceably together in $18^{\text {th }}$-century England, Brown's view is that "low-level" harmony and official leniency towards Catholics has been overstated. She argues that stereotypes of Catholics often "fed off and into everyday experience" (57), whether it be in the discussions which took place over the enforcement, or not, of national laws at a local level (such as in the case of travel licences), or in the way in which broader clichés could shape local prejudices and vice versa, sustaining the belief in the necessity of penal laws against Catholics. Brown suggests that penal laws in place on estates belonging to Catholics led the latter to engage in shady financial practices to secure inheritance on property, which only served to reinforce the negative stereotypes which abounded about their "hoarding the country's wealth in order to bring down the Protestant succession"(66). Questions remain however-and Brown acknowledges them herself-as to what extent the experience of well-off, propertied Catholics reflects the broader experience of the Catholic population of England. The author's assertion that such dubious financial methods were a matter of "survival" $(68,70)$ and fed into "low-level" or "everyday" 
anti-Catholicism is perhaps to be qualified, given the high social and economic standing of the families studied. Indeed, in his landmark essay on the Gordon rioters, who also targeted Catholics and their property, George Rudé asserted that there was a "deeper social purpose" to the attacks. He argues, "There was, in fact, a distinct class bias in the direction of the attack made by the rioters on the Roman Catholic community [...] it was the gentleman, the manufacturer, the merchant, or the publican, rather than the independent craftsman or the wage-earner, who was the main object of the rioters' attention" (109). ${ }^{1}$ The intersection of religious hatred and "class bias" is perhaps an area which requires further exploration outside the scope of this book.

6 Part two focuses in depth and in detail on the strategies and discourses adopted by Protestant writers, pamphleteers and propagandists to disparage Catholicism in $17^{\text {th }}$ century England, and also includes a final-ostensibly stand-alone-chapter on "doctrines of hatred" at the turn of the $20^{\text {th }}$ century. The first three chapters of the section examine the written production of Protestant authors-Lucy Hutchinson in Claire Gheeraert-Graffeuille's essay, Protestant clerics in Sandrine Parageau's work, and John Milton and Algernon Sidney in Christopher Hamel's contribution-and examine the fine line between virulent anti-popery propaganda on the one hand, and stringent criticism of the insufficiencies of Reformed Protestant government and education on the other.

7 As Claire Gheeraert-Graffeuille explains, an author such as Lucy Hutchinson, seeking to elevate the achievements of her late husband-regicide and governor of Nottingham during the Civil War-could at once denounce the descent into 'popish' iniquity which preceded and, in her view, triggered civil strife, while also showing that Puritans, in particular of the Presbyterian brand, had themselves largely had a hand in undermining attempts to institute a robust godly republic. The author thus argues that for Hutchinson, "Popery and Puritanism were two sides of the same coin, and revealed an analogous moral baseness" (88). In a similar vein, Sandrine Parageau highlights how Protestant criticism of the culture of ignorance that was seen as characterising Catholic teachings and faith could easily become a form of criticism of a Protestant establishment which had failed to adequately distance itself from popery and to impart knowledge on ordinary Protestants, leaving its flock prey to Jesuit attempts at conversion. As Parageau states, "ignorance was seen as one of the most insidious legacies of "popery" in the Church of England" (99) and also gave rise to debates over who indeed could reach salvation and who was irrevocably damned. These tensions and mutual dependence are also brought to the fore by Christopher Hamel who suggests that despite John Milton and Algernon Sidney being radical Protestants, steeped in a Puritan culture which rejected the persistence of Catholic liturgy and influence in England, they mobilised rationalist rather than theological arguments to justify resistance to a monarch-in the Civil War of the 1640s and in the Exclusion Crisis of the 1680s-to make their case for freedom. There was an acknowledged and familiar tradition of resistance to kingly tyranny within the Catholic tradition, Hamel argues. Thus, both thinkers were careful to distance themselves from accusations of being papists in disguise by relying on arguments of natural reason to justify resistance to a usurping monarch. For Hamel therefore, "their anti-Catholicism was thus the result, not the cause of their struggle, which was grounded on a reason-based account of the human motives for living in a civil society" (124). 
8 If the previous three chapters are anchored in a particular temporal and historical framework, the final essay of this section takes the reader to turn-of-the-century France and the writings of Anatole Leroy-Beaulieu whose spirited criticism of the three 'doctrines of hatred', as he termed them (antisemitism, Anti-Protestantism and anticlericalism), is revisited and given contemporary resonance by Valentine Zuber. In Zuber's reading, Leroy-Beaulieu equated all three 'antis', seeing them as encapsulating a similar "fear of outsiders" and endangering "democratic debate" through their respective-and parallel-attempts at reclaiming a certain form of pure nationhood which would "shield the French spirit from any outside cultural influences" (133). After explaining the way in which Leroy-Beaulieu refused the premises of anti-Protestantism (a lesser-known phenomenon that the other two 'antis'), the author draws upon the work of Pierre Birnbaum and Patrick Cabanel and re-considers Leroy-Beaulieu's thought to tentatively add to an ongoing debate into what she aptly sums up as "France's difficult relationship with pluralism" (141).

10 Part three of the collection revisits the intersection of religious prejudice and patriotism to investigate how Catholicism could also be held up as the epitome of antiEnglishness in order to bolster national confidence at times of crisis. In her article on the writings on English emigrant nuns in convents in Europe, Laurence Lux-Sterritt argues that while few anti-Catholic texts dwelled on the role of women in perpetuating recusant persistence, choosing instead to emphasise the insidious actions of Jesuits, those who did-in particular the two authors who provide the focus for this articletended to portray women as victims of depraved priests and confessors trapped in institutions where "unimaginable horrors" occurred (153) and where lewd sexual exploitation went on behind the walls of their enclosed spaces. Such representationswhich focused very little on the women themselves - served to discredit Catholics and denounce the inherent wickedness of the Catholic Church while also elevating the moral rectitude of Protestants. In such accounts, nuns were little more than "a curiosity" (160) and source of titillation and entertainment.

11 Claire Boulard-Jouslin also discusses how anti-Catholicism and Englishness were subtly and successfully equated in the writings of poet and essayist Joseph Addison, whose anti-Catholicism, the author argues, was a persistent feature of both his overtly political work and his writings on manners. The author demonstrates that although Addison's anti-Catholicism was not virulent or zealous in the mold of $17^{\text {th }}$-century commentators, or even some of his contemporaries, its pervasiveness and incursion into matters of lay practice (female fashion and societal mores, for instance) went some way to reshaping definitions of English politeness as inherently Protestant. The relative moderation of his anti-Catholicism enabled such views to be packaged as enlightened and tolerant rather than fanatical. Boulard-Jouslin contends that "debunking Catholicism was inherent in his overall project of promoting a new consensual form of politeness based on moral reform, good humour and culture, and defined as distinctly British" (171).

12 In a similar vein, Marc Martinez's article on the prevalence and variety of anti-Catholic tropes on the London stage during and after the 1745 Jacobite rebellion considers how religious propaganda could be mobilized in the service of the commercial ambitions of theatre managers at the major venues of Covent Garden and Drury Lane over the 1745 and 1746 seasons, as managers "capitalize[d]" (184) on anxieties linked to the landing 
of the Stuart Pretender and his march from Scotland through the North of England to put on plays which fueled patriotic and nationalistic sentiment. Theatregoers were offered historical dramas where religious disputes were played out, tapping into prevailing anti-Catholic prejudices, but audiences could also attend a more "motley type of performance", more hybrid forms of farce, satire and pantomime which allied "the spectacular appeal of a popular form and the emotional excitement of patriotic sentiment, the exhilarating thrill of theatre and the terrible scares of Papism" (195).

13 In the concluding article of this section, James Ward considers how the language of slavery and enslavement could be employed in Irish literary and civic writings of the late seventeenth and early eighteenth centuries, sometimes to emphasise the "selfinflicted" (221) subjugation of Irish Catholics, on occasions to denounce Ireland's political subjugation to England. Such "political slavery" (confirmed by the Declaration Act of 1719) was condemned in the writings of Jonathan Swift. The author acknowledges how Swift's anti-slavery discourse in the context of Ireland's political status jarred with his financial contribution to the South Sea Company's exploitation of African chattel labour, particularly seen through a contemporary lens.

Opening the final section on the demise of anti-Catholicism, Martin Mitchell's chapter charts the impact of Irish immigration to the West of Scotland between 1800 and 1914 on anti-Catholic rhetoric and behaviour, particularly from the perspective of the Protestant middle classes and the Presbyterian clergy. The author argues that despite some high watermarks of anti-Catholicism (for instance in the No Popery campaign of the 1850s in the wake of the Irish famine), local level studies highlight the Protestant middle class's distaste for militant anti-Catholicism (on the part of the Orange Order for instance, populated in the main by Irish Protestants), their engagement in charitable initiatives to alleviate the suffering of poor Irish Catholics, as well as moderately successful attempts at encouraging conversion, particularly among children who were placed with foster or adoptive families. Such findings add to a picture of waning antiCatholicism within both working communities and the Scottish middle class.

15 Alan Ford examines the figure of William Kerr and his tenacious (if ultimately outmoded) commitment to stringent anti-Catholicism within sermons and writings within the Church of Ireland at a time when the binary opposition of Protestantism versus Catholicism was receding from view and as calls for pan-Christian unity in the face of communism were on the rise. Ford explains how, despite the fact that he "firmly identified himself as Irish" (240), Kerr's opposition to a single Irish State run from Dublin led him to join the Covenant movement against Home Rule and in support of partition. In the churchman's historical works where, according to Ford, he adopted the role of a barrister defending his case rather than an objective historian, Kerr claimed that the early Church of Ireland's links with Rome were tenuous, thus accentuating a specifically Irish religious heritage.

16 The question of changing attitudes to sectarianism is also at issue in Karine Bigaud's searching article about the attempts made by the post-conflict Orange Order to "change its public image" (257) as less an organ of anti-Catholicism than an organisation open to the outside, keen to alter its reputation and inform the uninitiated about its membership, goals and history. Through a study of the two branches of the Museum of Orange Heritage, Bigaud highlights the Order's shift from open sectarianism to 'persuasion politics', a tactic associated in the recent past with a nationalist political strategy than that of Protestant Unionism. 
17 In "The Rise and Fall of Anti-Catholicism in Scotland" Sir T. M. Devine and Michael Rosie temper what they deem to be sensationalist headlines in the contemporary Scottish press about the apparent increase in hate crimes against Catholics in Scotland. Using historical evidence and sociological data, they convincingly demonstrate that the long-standing scourge of anti-Catholicism in Scotland has been on the wane since the 1960s across institutions, employment and the private sphere and pales in comparison with incidences of racist or gender-related offences. They put paid to the idea that sectarian intolerance is on the rise again and castigate the irresponsibility of certain news groups for perpetuating a narrative of bigotry in the interests of securing a catchy headline: "sectarianism, it seems, sells", they note (286).

John Wolffe concludes the section, and the collection, by calling for renewed interest in the reasons for the rise of anti-Catholicism in the $19^{\text {th }}$ century. He also provides a vital synopsis of the contributions made by each author to the debate and reiterates the importance of the book in its field. It is indeed a searching and empirically valuable collection of articles which includes some well-documented and persuasive case studies from researchers working across periods and fields. They provide insight into how minorities have put up resistance to state-sponsored persecution and how stereotypes can be used to reinforce power structures in place. There could be fruitful areas of cross-fertilisation with other related questions. For instance, it could be interesting to consider the intersection of anti-Catholicism with intolerance of and discrimination against Protestant Dissenters of different persuasions. The links between religion, class and gender-pointed to in Mitchell and Lux-Sterritt's work-could perhaps be taken further. Despite the frequent allusions to the spectre of international treason tied up with Catholicism across Britain and Ireland, it would perhaps be interesting to consider further anti-Catholicism from an international standpoint. Gaby Mahlberg's work on the complex lives of English Republican exiles in $17^{\text {th }}$-century Europe is a good example of such work which reinforces the view put forward in this collection that the narratives and experiences of Protestants and Catholics were far from polarised, even in the century which, according to John Morrill, saw the end of the 'wars of religion'.

\section{NOTES}

1. Rudé, George F. E. "The Gordon Riots: A Study of the Rioters and Their Victims: The Alexander Prize Essay." Transactions of the Royal Historical Society 6 (1956): 93-114. 
INDEX

Mots-clés: Catholicisme, Protestantisme, religion, histoire, persécution, patriotisme

Keywords: Catholicism, Protestantism, religion, history, persecution, patriotism

\section{AUTHORS}

\section{RACHEL ROGERS}

Maître de conférences

Université de Toulouse Jean Jaurès

rachel.rogers@univ-tlse2.fr 